\title{
A política externa brasileira para refugiados: entre a lógica das consequências e a lógica da adequação
}

\author{
The Brazilian Foreign Policy for Refugees: between the \\ logic of consequences and the logic of appropriateness
}

DOI: 10.5752/P.2317-773X.2017v6.n1.p5

\author{
Fernanda Cristina Nanci Izidro Gonçalves ${ }^{1}$ \\ Gustavo do Amaral Loureiro² \\ Flávia Barros Ornellas ${ }^{3}$
}

Recebido em: 28/03/2017

Aceito em: 16/08/2017

\begin{abstract}
RESUMO
O objetivo deste trabalho é analisar, a partir de uma perspectiva construtivista, qual lógica orientou o comportamento brasileiro no tratamento do refúgio desde os anos 1950 até o governo Dilma Rousseff (2011-2016). Utilizando a abordagem sobre lógica da adequação e lógica das consequências, este artigo parte da constatação de que embora o Brasil seja reconhecido como um país que respeita os direitos humanos e acolhe refugiados, nem sempre o seu comportamento refletiu uma abordagem solidária e alinhada às normas para tratamento do tema. Durante diferentes fases, a lógica das consequências se impôs na política externa brasileira, limitando a adesão do Brasil às normas internacionais que regulamentavam a acolhida aos refugiados e guiando suas ações para viés mais pragmático do que humanitário. A partir dos anos 1990, com o processo de redemocratização e reforço dos direitos humanos como tema central no ordenamento doméstico e internacional, a política brasileira para refugiados orientou-se conforme a lógica da adequação, refletindo um processo mais amplo de participação ativa do Brasil na ordem internacional. No entanto, conclui-se que a lógica da adequação ainda convive com a lógica das consequências na política brasileira para refugiados.
\end{abstract}

Palavras-Chave: Política Brasileira para Refugiados. Lógica da Adequação. Lógica das Consequências. Política Externa.

\section{Abstract}

This paper analyzes, from a constructivist perspective, which logic guided the Brazilian refugee policy since the 1950s to Dilma Rousseff administration (20112016). Using the logic of consequences and the logic of appropriateness approach this paper suggests that although Brazil is recognized as a country that respects human rights and welcomes refugees, not always its behavior reflected this approach aligned to standards of refugee and human rights. During different phases, the logic of consequences was strong on Brazilian foreign policy, limiting Brazil's adherence to international standards that regulated refugee reception, with a more pragmatic than humanitarian foreign policy. From the 1990s, Brazilian refugee policy started to reflect the logic of appropriateness, immersed in a broader process of Brazil active participation in international regimes. However, it is concluded that although Brazilian refugee policy is marked by the logic of appropriateness, it is still characterized by the logic of consequences too.

Keywords: Brazilian refugee policy. Logic of Appropriateness. Logic of Consequences. Foreign Policy.
1. Doutoranda em Ciência Política pelo Instituto de Estudos Sociais e Políticos (IESP/UERJ). Atualmente é coordenadora adjunta e professora do curso de Relações Internacionais do Unilasalle-RJ, coordenadora adjunta e pesquisadora do Núcleo de Estudos Atores e Agendas de Política Externa (NEAAPE) e pesquisadora do Observatório Político Sul-Americano (OPSA). Orcid: 0000 0002-1849-1317.

2. Mestrando em Ciência Política na Universidade Federal do Estado do Rio de Janeiro (Unirio), bacharel em Relações Internacionais pelo Unilasalle-RJ e pesquisador do projeto de Direitos Humanos e Relações Internacionais desta instituição. Orcid: 0000-00027429-7172.

3. Graduanda em Direito pela Universidade Federal Fluminense (UFF) e em Relações Internacionais pelo Unilasalle-RJ. Orcid: 0000-0001-5186-8115. 
Introdução

Mundialmente, os refugiados são reconhecidos como indivíduos que procuram abrigo em outros países por possuírem um bem fundado temor de perseguição em virtude da sua raça, religião, nacionalidade, opinião política ou pertencimento a certo grupo social (JUBILUT, 2007). Embora o tema tenha alcançado maior destaque nas discussões acadêmicas e políticas na atualidade, essa questão não é nova. Normas internacionais que versam sobre o assunto, começaram a ser construídas a partir da Convenção de 1951, com a elaboração do Estatuto dos Refugiados no âmbito da construção do Regime Internacional de Direitos Humanos. Ao longo das décadas, outras normas foram introduzidas, ampliando a definição e aplicação do instituto do refúgio como o Protocolo de 1967 Relativo ao Estatuto dos Refugiados, a Convenção Relativa aos Aspectos Específicos dos Refugiados Africanos de 1969 e a Declaração de Cartagena de 1984 (BARRETO, 2010; JUBILUT, 2007).

Segundo dados do Alto Comissariado das Nações Unidas para Refugiados (ACNUR), atualmente o número de pessoas deslocadas é o maior já registrado desde a Segunda Guerra Mundial, envolvendo mais de 60 milhões de indivíduos. No cenário atual, o Brasil reconhece a presença de cerca de 9.000 refugiados no país, segundo dados do Comitê Nacional para os Refugiados (CONARE) (ALTO COMISSARIADO DAS NAÇÕES UNIDAS, 2016). O país é signatário dos principais tratados de Direitos Humanos e possui uma legislação sobre refúgio considerada pioneira entre os países latino-americanos, a Lei 9.474 de 1997. Todavia, nem sempre o posicionamento brasileiro foi de um país acolhedor de refugiados, como se pode pensar à primeira vista. Embora inicialmente o Brasil tenha se inserido nas discussões do Regime Internacional de Refugiados em construção no âmbito das Nações Unidas nos anos 1950, durante o período da ditadura militar o governo brasileiro manteve um posicionamento distante da temática, tornando-se não um receptor de refugiados, mas apenas um país de trânsito, servindo ao reassentamento. Apenas nos anos 1990 o Brasil se inseriu de forma mais ativa no tratamento da questão, inserida no campo de discussão dos Direitos Humanos.

Considerando a mudança no tratamento brasileiro da questão e a importância da discussão desse tema na atualidade, o objetivo deste trabalho é analisar, a partir de uma perspectiva construtivista, a política brasileira para refugiados, compreendendo a mudança do tratamento do refúgio pelo governo brasileiro ao longo do tempo, desde os anos 1950 até o governo Dilma Rousseff (2011-2016), entendendo que lógicas orientaram o tratamento brasileiro da questão. Para tanto, este trabalho fundamenta-se nos conceitos de lógica da adequação e lógica das consequências. No que tange à metodologia, este artigo é de natureza explicativa e baseado em um estudo de caso sobre a política brasileira para refugiados.

Este artigo está dividido em 3 seções, além desta introdução. A seção a seguir apresenta a perspectiva que orienta a pesquisa, explorando os conceitos de lógica da adequação e lógica das consequências. A seção seguinte trata da política brasileira para refugiados dos anos 1950 ao governo Dilma Rousseff (2011-2016), compreendendo como o comportamento 
do país se orientou conforme as lógicas de ação discutidas na seção anterior. Por fim, é oferecida uma conclusão sobre o tema estudado.

Quadro analítico: lógica da adequação e lógica das consequências

Embora exista nas Relações Internacionais uma gama de teorias que podem ser utilizadas para entendermos diferentes fenômenos, este artigo parte da perspectiva construtivista das Relações Internacionais para investigar a política brasileira para refugiados. Para tanto, são abordadas duas lógicas de ação que orientam a conduta brasileira no período analisado: a lógica da adequação e a lógica das consequências. Contudo, antes de apresentar e discutir estas lógicas é importante clarificar o conceito de regime internacional, visto que a discussão sobre o tema do refúgio na política brasileira é concomitante ao estabelecimento de um regime sobre a temática, através do qual foram criadas normas e regras que $\mathrm{o}$ governo brasileiro buscou se adaptar ao longo dos anos.

No campo das Relações Internacionais, o termo regime internacional é utilizado para referir-se a um conjunto de princípios, normas, regras e procedimentos que orientam as ações dos atores internacionais. Esta definição bastante disseminada na área, apoia-se na contribuição de Krasner (1982) que argumenta que os regimes são compostos por crenças que podem se manifestar através da institucionalização político-jurídica ou pela institucionalização de comportamentos (princípios); por padrões de comportamentos que se refletem em direitos e obrigações (normas); por prescrições ou proibições específicas para a ação (regras); e por práticas coletivas dominantes que implantam princípios e mudam as regras (procedimentos).

$\mathrm{Na}$ visão construtivista das Relações Internacionais os regimes internacionais são percebidos como instrumentos socialmente construídos que codificam um conjunto ou uma estrutura de identidades e interesses e geram padrões de comportamento apropriados que se refletem em obrigações e direitos (FINNEMORE; SIKKINK, 1998). Assim, a criação de regimes, bem como a identificação dos interesses dos Estados nestes regimes, é definida socialmente, a partir do padrão de interação estabelecido ${ }^{4}$.

A origem do Regime Internacional de Refugiados está estritamente ligada à emergência do Direito Internacional dos Direitos Humanos, seja como base para os princípios ou como fonte de normas que passam a ser adotadas no âmbito de proteção aos refugiados. Segundo Piovesan (2001), a proteção internacional dos refugiados é operada mediante uma estrutura que deriva da mesma base filosófica que a proteção internacional dos direitos humanos. Nesse sentido, Jubilut (2007) explicita que os pilares que iniciaram a positivação dos direitos humanos, oriundos da Declaração Universal dos Direitos do Homem e do Cidadão, de 1789, são os mesmos que regem o instituto do refúgio e, portanto, as normas do Regime Internacional de Refugiados: a liberdade, a igualdade e a fraternidade. Inclusive, no artigo 14 da Declaração Universal dos Direitos Humanos, criada no seio da Organização das Nações Unidas (ONU), em 1948, consta a disposição de que "toda pessoa sujeita a perseguição tem o direito de procurar e de beneficiar de asilo em outros países" (ORGANIZAÇÃO
4. Outras perspectivas teóricas compreendem de forma diferente os regimes internacionais. 0 realismo, por exemplo, parte do pressuposto que os regimes internacionais refletem os interesses dos atores mais poderosos, enquanto os neoliberais enfatizam os dilemas de cooperação e conflito entre os Estados, que precisam estabelecer regras para sua interação através de regimes para contornar os efeitos da anarquia internacional. Para uma discussão teórica sobre regimes, ver: Rittberger, Mayer e Hasenclever (2000) 
DAS NAÇÕES UNIDAS, 1948), salientando a conexão entre a consolidação dos dois regimes internacionais.

Todavia, embora os Regimes de Refugiados e de Direitos Humanos partam do mesmo fundamento, distinguem-se quanto às suas abrangências. O primeiro trata da proteção do ser humano perseguido em função de sua raça, religião, nacionalidade, opinião política e pertencimento a grupo social, enquanto o segundo objetiva também assegurar condições mínimas para que o homem sobreviva e possa buscar felicidade (JUBILUT, 2007).

Em paralelo à construção do Regime Internacional de Refugiados, consolidou-se também o Direito Internacional Humanitário, constituído por normas criadas a fim de regulamentar os problemas causados pelos conflitos armados (JUBILUT, 2007). Desta forma, consolidou-se no sistema internacional um amplo sistema de proteção da pessoa humana, composto pelo Direito Internacional dos Direitos Humanos, pelo Direito Internacional Humanitário e pelo Direito Internacional dos Refugiados, cujas convergências contribuem para "assegurar a proteção do ser humano em todas e quaisquer circunstâncias" (TRINDADE, 1997, p.174).

Contudo, mesmo com o avanço na criação de dispositivos legais para proteção dos indivíduos, Barnett e Finnemore (2004) ao analisarem a evolução das atividades do ACNUR desde sua criação em 1950 mostraram que apesar de existir um esforço para garantir proteção e assistência humanitária à população refugiada no contexto do pós Segunda Guerra Mundial, havia um consenso de que este compromisso não poderia ferir a soberania dos Estados, resultando na criação de uma organização submissa à vontade dos Estados e dependente de doações voluntárias. Apesar disso, o ACNUR foi capaz, ao longo dos anos, de expandir sua abrangência e remover algumas limitações, influenciando a percepção dos formuladores de política externa e da comunidade internacional, utilizando sua autoridade para auxiliar na expansão da definição da categoria de refugiado e no seu escopo de atuação geográfica, tendo que se adaptar aos interesses dos Estados-membros, mas ao mesmo tempo conseguindo estabelecer novas normas, regras e princípios que se tornaram práticas coletivas disseminadas.

Após esta breve apresentação do Regime Internacional de Refugiados, é importante trazer à luz as contribuições da teoria construtivista para este trabalho. Embora o construtivismo seja uma teoria com diferentes vertentes, em geral, os autores expoentes desta teoria compartilham a visão de que a realidade se encontra em processo de constante construção e reorganização, em um sistema de co-constituição, em que agente e estrutura são capazes de exercer influência um sobre o outro (MESSARI; NOGUEIRA, 2005). Nesta abordagem, as relações sociais têm lugar privilegiado, visto que são permeadas por normas, ideias, cultura, conhecimento e valores que operam como regras sociais capazes de unir agente e estrutura, ditando padrões de comportamento para os agentes. Todavia, os construtivistas também apontam que os agentes possuem certa liberdade, sendo capazes de utilizar as regras sociais como base para escolhas racionais, podendo descumpri-las desde que estejam dispostos a lidar com as possíveis consequências (ONUF, 1998). 
A esse respeito Finnemore e Sikkink (1998) salientam que não há uma oposição de regras e normas sociais à racionalidade. As autoras destacam que a racionalidade não pode ser separada das influências que as normas exercem, assim como o contexto normativo condiciona a escolha racional. Deste modo, contemplam em sua abordagem tanto fatores ideacionais como materiais.

Finnemore (1996) em National Interests in International Society apresenta duas lógicas de ação que podem orientar o comportamento dos Estados: a lógica da adequação e a lógica das consequências. O processo que orienta a lógica da adequação implica que os Estados internalizam as normas e os papéis que devem agir de acordo porque desejam se adequar ao cenário da política internacional e porque acreditam serem os mais adequados. Assim, os interesses dos Estados são construídos por meio das interações sociais, definidos no contexto de normas e entendimentos sobre o que é bom e adequado (FINNEMORE, 1996).

Esta lógica está relacionada à visão construtivista de que os Estados estão imersos em redes de relações sociais e transnacionais que modelam suas percepções do mundo e o papel que desempenham. Assim, os interesses nacionais são construídos no contexto das normas e valores compartilhados internacionalmente, que são capazes de modificar a atuação do Estado que, por sua vez, passa a agir de acordo com o sentido que confere para si e para os demais. Conforme o contexto normativo é modificado, mudanças também ocorrem nos interesses e comportamentos dos Estados. Assim prevalece a lógica da adequação, processo pelo qual instituições sociais e normas de comportamento conferem direção ao Estado.

Complementando esta visão, March e Olsen (2011), argumentam que agir apropriadamente significa proceder de acordo com as práticas institucionalizadas da coletividade, baseadas em compreensões mútuas do que é razoável e correto. O comportamento inerente à lógica da adequação implica a internalização das normas de forma consciente, já que os próprios agentes decidem se desejam defender princípios que acreditam ser morais e justos.

Em contraposição, a lógica das consequências é baseada na racionalidade. Nesta concepção, os Estados são atores racionais que buscam as melhores consequências tendo em vista os seus interesses e para isso desenvolvem estratégias para maximizar utilidades. A racionalidade implicar perseguir os próprios objetivos a fim de maximizar os ganhos individuais. Neste sentido, como a forma como os Estados se comportam no sistema internacional depende das estruturas que são formadas na interação entre os agentes - que sofrem influência da cultura na qual estão inseridos - as normas e os papéis desempenhados são criados neste contexto e podem ser utilizados para servir aos interesses dos Estados, que agem em termos de custo-benefício (FINNEMORE, 1996).

Finnemore (1996) afirma que separar as duas lógicas é conveniente em termos analíticos, mas não é necessariamente a realidade, pois os dois tipos de comportamento estão em interação. Assim, é possível que o Estado se insira em um contexto normativo movido por uma lógica, enquanto a forma de articulação deste contexto pode ser movida por outra. Deste modo, as lógicas se complementam: ocorre a lógica da adequação, 
na qual o Estado internaliza as normas compartilhadas no cenário internacional a fim de se adequar e, então, inserido nas regras e normas internacionais baliza sua ação pela lógica das consequências. Isto significa que mesmo existindo um contexto normativo que envolve e guia as ações do Estado, ele também se guia por objetivos materiais, pensados em termos de custo-benefício, de forma racional, como exposto anteriormente.

March e Olsen (2011) reforçam a necessidade de levar em consideração as interações entre as duas lógicas em ambientes institucionais distintos. Como regras e normas sociais possuem diversos tipos de consequências, muitas vezes os atores se deparam com dilemas em que o comportamento considerado apropriado pela lógica da adequação pode resultar em resultados negativos, enquanto o comportamento orientado pela lógica das consequências, tem a possibilidade de gerar resultados mais satisfatórios ao Estado. Por esta razão é imprescindível analisar o contexto normativo no qual o Estado está inserido, suas preferências e interesses, o papel que deseja desempenhar no sistema internacional e sua adaptação às regras e normas dos regimes internacionais ao longo do tempo.

A utilização destas lógicas para entendermos a política do Brasil para refugiados permite demonstrar que as duas lógicas estão presentes e interagem neste âmbito específico da política brasileira. Demonstra-se nas seções seguintes, que a política brasileira para refugiados é informada por regras e normas, que foram internalizadas ao longo do tempo no comportamento do país e que guiam seu envolvimento em questões internacionais relacionadas ao tema, além de orientar a adoção de políticas públicas para o tratamento da questão. Todavia, não é apenas uma dimensão normativa que faz parte das decisões do governo brasileiro. Argumenta-se que para além do plano normativo, existe uma lógica das consequências, que determina as ações do país e os ganhos que quer obter no sistema internacional. Assim, procura-se demonstrar que a política brasileira para refugiados convive ao longo do tempo tanto com motivações racionais como normativas presentes no comportamento do Brasil no que diz respeito à sua participação no Regime Internacional de Refugiados.

Entre a lógica das consequências e a lógica da adequação:

a política brasileira para refugiados

Ao observarmos o desenvolvimento da política brasileira para refugiados utilizando a abordagem sobre a lógica da adequação e a lógica das consequências, percebe-se que durante diferentes fases, a lógica das consequências se impôs na política externa brasileira, limitando a adesão do Brasil às normas internacionais que regulamentavam a acolhida e a proteção aos refugiados, guiando suas ações para viés mais pragmático do que humanitário, como apresentado a seguir.

O Estado brasileiro não tardou em comprometer-se com as normas relativas à proteção dos refugiados, recepcionando a Convenção de 1951 em seu ordenamento jurídico no ano de 1960 através do Decreto-Legislativo 11, promulgado através do Decreto 50.215 de 1961 (JUBILUT, 2007). A Convenção de 1951 estabeleceu, no âmbito do ACNUR, o conceito de refugiado como aquele que busca proteção "temendo ser perseguido por 
motivos de raça, religião, nacionalidade, grupo social ou opiniões políticas, se encontra fora do país de sua nacionalidade e que não pode ou, em virtude desse temor, não quer valer-se da proteção desse país" (CONVENÇÃO RELATIVA AO ESTATUTO DOS REFUGIADOS, 1951).

Esta Convenção também consagrou o princípio de não devolução (non-refoulement) segundo o qual, nenhum país pode expulsar um refugiado contra a vontade do mesmo, em nenhum caso, para um território onde sofra perseguição. Todavia, a Convenção estabeleceu reservas geográfica e temporal, pois eram considerados refugiados apenas pessoas de origem europeia (em decorrência da Segunda Guerra) e que sofreram perseguição até $1^{\circ}$ de janeiro de 1951. O Brasil, na ocasião, manteve postura favorável a reserva geográfica (MOREIRA, 2012). Na mesma época, em 1958, o país integrou o Conselho Executivo do ACNUR, órgão do qual faz parte até hoje.

Nesta primeira etapa, o governo brasileiro recebeu uma gama de refugiados europeus, tornando-se o principal receptor de refugiados na região da América do Sul. Os refugiados eram compreendidos como uma importante força de trabalho que auxiliaria no projeto de desenvolvimento nacional. A política de refugiados se confundia nesta época com a política imigratória, embora fosse compreendido que a questão dos refugiados envolvia causas humanitárias. Contudo, o governo brasileiro tratava estes indivíduos como imigrantes e adotava uma política de caráter seletivo, baseando-se na recepção de refugiados europeus selecionados a partir de critérios "desejáveis". A esse respeito, desde o final da Segunda Guerra Mundial, o Brasil se mostrava favorável ao acolhimento dos refugiados europeus. Hélio Lobo, representante do governo brasileiro junto à Comissão Preparatória para a Criação da Organização Internacional de Refugiados 5 , afirmava em 1947:

por motivos de ordem financeira, a recepção de imigrantes no Brasil depararia grandes obstáculos se, em consequência da guerra, não se nos abrisse agora oportunidade favorável. Como? Pelo custo de cada imigrante, isto é, cerca de 70 cruzeiros por cabeça, em vez de 3 a 4 mil, que é o que significaria a adoção do antigo sistema de procura na Europa (LOBO, 1947 apud SALLES, 2007, p.192).

Ainda em seu discurso é possível corroborar a seletividade no acolhimento dos refugiados pelo governo brasileiro:

\begin{abstract}
se trata de elementos humanos com excelentes títulos físicos, profissionais, religiosos, sociais e morais, como raramente acontece nas aglomerações ou grupos sociais à emigração. [...] É preciso observar esses grupos nos campos ou fora deles para ter-se uma ideia do que representam - gente sadia, de estatura elevada, com aquele senso do trabalho, de família e de religião, desde simples operários até professores universitários, médicos ou engenheiros. [...] note-se sobre a índole conservadora, anti-comunista, esta segunda característica favorável [...]” (LOBO, 1947 apud SALLES, 2007, p.193).
\end{abstract}

A integração dos refugiados ao país contava com órgãos estatais (responsáveis pela acomodação, alimentação e transporte interno) e com apoio de organizações internacionais (responsáveis pelo transporte marítimo e despesas iniciais). No que tange à legislação nacional que tratava dos refugiados, era a mesma referente à política imigratória (MOREIRA, 2012).
5. A OIR foi criada em 1948 e se dedicava aos problemas residuais dos refugiados da Segunda Guerra Mundial. Em 1950, a OIR foi substituída pelo ACNUR, instituição que até hoje é responsável pelo tratamento do tema do refúgio no âmbito da ONU (BARRETO, 2010). 
Assim sendo, durante os anos 1950 o governo brasileiro utilizou as normas que emergiram no regime internacional de refugiados de forma racional, existindo uma predominância da lógica das consequências no comportamento brasileiro. Para além de preocupações humanitárias, sobressaiu no recebimento de refugiados europeus os interesses voltados a integrá-los como importante força de trabalho, capaz de contribuir para o desenvolvimento econômico do país. Embora se inserisse nas discussões internacionais, assinando e ratificando a Convenção de 1951, com efeito, os interesses nacionais precediam os ideais de direitos humanos nessa época, evidenciado na política seletiva para refugiados adotada pelo governo brasileiro ao longo do período. Assim, percebemos que o país agia em prol de um cálculo custo-benefício, aderindo às normas e desempenhando um papel de receptor de refugiados que servia aos interesses brasileiros - tanto de integrar-se às discussões internacionais como de fomentar o desenvolvimento nacional a partir da seleção de migrantes considerados "desejáveis".

Nos anos 1960, há uma mudança na política brasileira para refugiados com a instauração do regime militar. O caráter autoritário do governo refletiu-se em sua política externa, com a segurança sendo considerada a condição essencial para o desenvolvimento brasileiro. A política doméstica reforçava na política externa um caráter securitário que atingiu o tema da imigração, tornando o imigrante um potencial perigo à nação. A partir dos anos 1970, a política começou a se tornar mais restritiva, com aplicação de diversos critérios técnicos não somente no âmbito da imigração, mas também no refúgio, seguindo as diretrizes expostas pelo Conselho de Segurança Nacional que expunha preocupação em acolher grupos terroristas e pessoas que se opunham a regimes semelhantes ao brasileiro (MOREIRA, 2012).

A ameaça comunista estava, portanto, associada também ao âmbito dos refugiados. Também a preocupação em receber grandes contingentes populacionais, preocupação de natureza demográfica e populacional, faziam parte da política brasileira para refugiados ao longo deste período, pois o governo não desejava aumentar muito a população em seu território (MOREIRA, 2012). Nesta época a política deixa de ser meramente seletiva para tornar-se, com efeito, restritiva.

Este período do governo militar marca a autonomia pela distância, fase que Gelson Fonseca Júnior (1998) caracteriza como marcada pelo afastamento do Brasil da discussão de temas sensíveis no sistema internacional que pudessem comprometer sua autonomia política. Nos anos 1970, portanto, o Brasil se inseria no sistema internacional não mais como um país disposto a receber imigrantes e refugiados. Preocupado com outras questões afetas à segurança e desenvolvimento, as preocupações humanitárias não faziam parte de suas prioridades domésticas e internacionais. A política externa adotada pelo país ao longo deste período teve consequências para a imagem internacional do país, percebido como violador de direitos humanos. Com efeito, o governo repressivo e a postura adotada em discussões internacionais sobre o tema, como no âmbito do refúgio, repercutiam negativamente para o país, pois apontava a preponderância de uma política que defendia a soberania nas decisões ao invés da adequação aos regimes internacionais. 
É interessante destacar que nesta fase, inclusive, embora diversos países pleiteassem a revisão de Convenção de 1951 com a suspensão das reservas geográfica e temporal, o governo brasileiro discordava da retirada das reservas, justificando o seu temor a partir de argumentos socioeconômicos, demográficos e financeiros. A elaboração do Protocolo sobre o Estatuto dos Refugiados em 1967 ilustra este fato. A posição brasileira só foi alterada, no sentido de apoiar o Protocolo e a suspensão das reservas quando o país percebeu que a maioria dos Estados no ACNUR apoiava a mudança proposta pelo instrumento jurídico. O Protocolo só foi promulgado em 1972 no Brasil (MOREIRA, 2012), não entanto, não teve validade efetiva, pois na prática o governo militar brasileiro manteve a limitação geográfica, reconhecendo como refugiados apenas indivíduos provenientes da Europa (JUBILUT, 2007).

Esta postura coincide com um período em que a região estava inserida no contexto de ditaduras e violações dos direitos humanos, que geravam um grande contingente de refugiados latino-americanos provenientes dos regimes ditatoriais e das instabilidades políticas. Na década de 1970, nesse contexto de regimes de exceção que perseguiam cidadãos e os forçavam a buscar abrigo no exterior, o ACNUR volta-se à América Latina, celebrando um acordo com o Estado brasileiro para estabelecer um escritório ad hoc em território nacional a fim de buscar uma resolução para a crise de refugiados na região. O Brasil impôs a condição de manter a limitação geográfica estabelecida na Convenção de 1951, aceitando somente refugiados provenientes do continente europeu, limitando a atuação do escritório do ACNUR ao reassentamento dos refugiados de países vizinhos e demais locais que chegavam ao território brasileiro. O governo brasileiro acreditava que a instalação de um escritório no país teria um impacto positivo em sua credibilidade internacional no período em que duras críticas eram dirigidas ao autoritário governo brasileiro. Mas, mesmo com a instalação do ACNUR em seu território, o país recusava-se a mudar de posicionamento no que tange à implementação do Protocolo de 1967 (JUBILUT, 2007). Nesse sentido, há uma grande interseção entre o discurso do autoritário governo brasileiro de garantir a segurança nacional e a sua prática no plano interno e externo na área de refugiados.

Percebe-se assim, que ao longo deste período, o Brasil, apesar de também encontrar-se sob um regime autoritário, tornou-se um dos principais destinos de pessoas perseguidas de países vizinhos que atravessavam suas fronteiras em busca de abrigo, muitas delas sem condições documentais ou econômicas de deslocar-se para outro continente (BARRETO, 2010). Todavia, esse período foi caracterizado por uma "atuação quase clandestina" do ACNUR no Brasil, pois o governo não reconhecia seu mandato como organização internacional, o que tornou o escritório dependente do apoio de órgãos ligados aos direitos humanos que já atuavam no país, como a Cáritas Arquidiocesana do Rio de Janeiro, a Cáritas Arquidiocesana de São Paulo e a Comissão Pontifícia Justiça e Paz (JUBILUT, 2007, p.172).

Segundo Barreto (2010, p. 17): "A Cáritas Arquidiocesana do Rio de Janeiro e a de São Paulo, desde 1975, ajudaram argentinos, chilenos, uruguaios que procuravam acolhida no Brasil, mesmo com o risco de, se fossem descobertos, serem entregues ao governo do país de origem." 
Nos centros administrados pela Cáritas, os refugiados recebiam auxílios para alimentação e saúde, além de conta com assistência jurídica para garantir sua proteção. Entre os anos 1970 e 1980, o ACNUR, em parceria com estas organizações, conseguiu que refugiados cubanos, vietnamitas e famílias Baha i fossem recebidas no país e se estabelecessem na condição de imigrantes, o que minimizou a reserva geográfica defendida pelo governo brasileiro (MOREIRA, 2012; JUBILUT, 2007).

De todo modo, ao longo desta época a política brasileira se caracterizou como restritiva, visto que o país não recebeu e reconheceu formalmente refugiados, aceitando apenas a presença deles em situação de trânsito para reassentamento em terceiros países. Os inúmeros latino-americanos que entraram em território nacional foram tratados como turistas com autorização para permanência temporária no país, visto que seriam redirecionados a outro país de destino. Cerca de 20 mil refugiados foram assentados em países europeus, nos Estados Unidos da América (EUA), no Canadá, entre outros (JUBILUT; APOLINÁRIO, 2008). Não existiam regras que tratassem dos refugiados, apenas a legislação migratória.

Desta maneira, entende-se que durante a ditadura militar a lógica das consequências é ainda mais perceptível no comportamento brasileiro. Agindo de forma racional, o governo brasileiro delineou uma estratégia que contemplou seus interesses nacionais, direcionados naquele momento ao combate ao comunismo no plano doméstico e internacional, além do desenvolvimento. Assim, a lógica das consequências preponderou no comportamento nacional, havendo um congelamento dos direitos dos refugiados, tratados apenas com base na Convenção de 1951, enquanto o regime internacional de refugiados atualizava-se com o Protocolo de 1967 e com a Declaração de Cartagena em 1984.

A preocupação dos governos militares com os fluxos migratórios fez com que, durante esse período, os direitos dos refugiados não apresentassem desenvolvimento significativo em âmbito doméstico, estando subjugados aos interesses nacionais e à defesa nacional. Embora existisse uma influência sendo exercida pela estrutura de normas e valores internacionais, o governo brasileiro não se adaptava às novas normas, desempenhando papel contrário às tendências internacionais. A própria decisão de permitir a instalação de um escritório do ACNUR no país se deu com ressalvas, sem o reconhecimento formal das atividades da instituição. A lógica da busca pelas melhores consequências tendo em vista os interesses de segurança e desenvolvimento brasileiro dominou as políticas adotadas à época.

Em 1980, uma nova legislação migratória foi aprovada, a Lei 6.815, que se refere ao Estatuto de Estrangeiro. Esta lei não alterou o estatuto de refugiado, mas permitiu a aplicação do instituto de asilo, abrindo uma possibilidade que não existia no país até então. À época, latino-americanos, em especial cubanos, entre indivíduos de outras origens foram reconhecidos como asilados pelo governo brasileiro. (MOREIRA, 2012).

Destaca-se neste período a Declaração de Cartagena, assinada em 1984 após encontro na cidade com presença de diversos países latino-americanos. Essa declaração foi resultado do contexto de perseguição política e conflitos armados das décadas de 1970 e 1980 na América Latina, que 
influenciaram a adoção de um tratado de âmbito regional (MOREIRA, 2010). O principal resultado da declaração foi a ampliação do conceito de refugiado na região, que passou a incluir a violação massiva de direitos humanos, além dos motivos clássicos de reconhecimento. No entanto, o Brasil não participou do encontro e tampouco assinou a Declaração nessa época (MOREIRA, 2012).

As atividades do ACNUR no Brasil apenas foram reconhecidas formalmente pelo Estado brasileiro no ano de 1982, já ao fim do regime militar. Em 1989, após a redemocratização, o escritório do ACNUR foi movido para Brasília e, no mesmo ano, através do Decreto 98.602, o Brasil denunciou e removeu a reserva geográfica da Convenção de 1951, aderindo plenamente ao Protocolo de 1967 e orientando-se também pela Declaração de Cartagena, incorporada ao ordenamento jurídico nacional com a Constituição Federal de 1988 (BARRETO, 2010).

Com efeito, foi a partir da redemocratização do país que houve uma mudança efetiva na política brasileira para refugiados, trazendo importantes progressos na área de direitos humanos. O país reorientou sua política externa a partir do paradigma da autonomia pela participação (FONSECA JÚNIOR, 1998), através do qual entendia-se que era necessário participar das normas e instituições internacionais como forma de renovar as credenciais do país no mundo. Nesta época, o Brasil ratificou tratados internacionais sobre o tema dos direitos humanos além de reconhecer a legitimidade de organizações internacionais de controle de violações dos direitos humanos (MOREIRA, 2012). No âmbito doméstico, a Constituição Federal de 1988 estabeleceu como diretrizes norteadoras da política exterior brasileira a prevalência dos direitos humanos e a concessão de asilo político, trazendo avanços no tema. Assim, começa-se a vislumbrar nos anos 1980 que a lógica da adequação começa a orientar a política brasileira para refugiados, embora convivesse com a lógica das consequências.

Em 1991, o Ministério da Justiça estabeleceu uma dinâmica processual para guiar o processo de solicitação e concessão de refúgio no Brasil e de proteção aos refugiados, através da edição da Portaria Interministerial 394. O novo sistema incluía o ACNUR no processo, permitindo que o órgão realizasse uma entrevista com o solicitante de refúgio e, então, elaborasse um parecer recomendando ou não a concessão do refúgio, mas mantinha a decisão final com o governo brasileiro. O Ministério das Relações Exteriores avaliava o relatório fornecido pelo ACNUR, posicionava-se sobre o mesmo ${ }^{6}$ e enviava-o ao Ministério da Justiça para que este proferisse a decisão final (JUBILUT, 2007). Assim, o Estado brasileiro passou a se empenhar no tratamento da concessão do refúgio bem como na proteção aos refugiados, atuando de forma diferente do período anterior, do regime militar.

Até os anos 1990, o papel do Estado brasileiro limitava-se apenas ao fornecimento de documentos para os refugiados, não tendo grandes preocupações com o futuro dos indivíduos após a concessão do refúgio. Esse quadro passou a mudar com a chegada em grande escala de refugiados egressos de zonas de conflito como Angola, as repúblicas da ex-Iugoslávia, República Democrática do Congo e Libéria. Muitos destes in-
6. Segundo Jubilut (2007, p. 175), “0 Ministério das Relações Exteriores sempre decidiu em conformidade com 0 parecer da ACNUR". 
7. 0 Brasil orienta-se pela definição ampliada do conceito de refugiado, conforme a Declaração de Cartagena, embora ainda entenda que é necessário que exista coerção ou obrigação em fugir para a concessão do refúgio, o que é contrário à recomendação do documento (SALLES; GONÇALVES, 2016). divíduos possuíam problemas de saúde e traumas psíquicos causados ou agravados pela guerra, tornando necessário um maior esforço do Estado para integrá-los de maneira apropriada. Nesse cenário, diversas áreas do governo, como os Ministérios do Trabalho, Saúde, Educação e Relações Exteriores, em conjunto com a Cáritas Arquidiocesana do Rio de Janeiro e de São Paulo, trabalharam com o objetivo de aperfeiçoar os dispositivos de integração dos refugiados à força de trabalho, reconhecer os diplomas estrangeiros e oferecer apoio no tratamento da saúde física e mental para que os indivíduos em situação de vulnerabilidade pudessem desfrutar de uma maior qualidade de vida (BARRETO, 2010). É nesse contexto dos anos 1990 que se iniciam as discussões sobre o projeto de lei sobre o Estatuto Jurídico do Refugiado.

Os debates para criação desta legislação remontam ao contexto de discussão internacional sobre direitos humanos, integrado como novo tema na agenda internacional e nacional. A Declaração e Programa de Ação de Viena de 1993 propunha a criação de iniciativas para lidar com os problemas de refugiados e reforçava a interdependência entre direitos humanos, democracia e desenvolvimento. Estes aspectos foram valorizados pelo governo brasileiro, visto que era importante no contexto de consolidação do regime democrático criar instituições que fossem comprometidas com valores violados no período autoritário. Dando continuidade à postura mais proativa na área de direitos humanos, o governo Fernando Henrique Cardoso engajou-se em prol das recomendações da Declaração de Viena, criando inclusive um Programa Nacional de Direitos Humanos que envolvia tanto setores governamentais como atores da sociedade civil (MOREIRA, 2012).

O projeto em discussão foi aprovado como a Lei 9.474 no ano de 1997, criando uma legislação nacional que trata especificamente do reconhecimento de refugiados, sendo considerada, inclusive, inovadora no contexto latino-americano. Este instrumento jurídico adotou oficialmente uma definição mais ampla de refugiado, acolhendo indivíduos que fogem de graves e generalizadas violações de direitos humanos, consolidando o Brasil como um Estado acolhedor de refugiados e integrando-o formalmente ao grupo de Estados que efetivam o Direito Internacional dos Direitos Humanos no que tange ao Direito Internacional dos Refugiados (JUBILUT, 2007)7 . A lei é considerada pela própria ONU como uma das mais modernas, abrangentes e generosas do mundo ao contemplar todos os dispositivos de proteção internacional aos refugiados e criar o CONARE, responsável pela política pública do refúgio e efetivação das solicitações de refúgio em todo o país (BARRETO, 2010).

O CONARE é um órgão misto, integrando público e privado, órgãos do governo responsáveis pela integração social e laboral, pela saúde pública e pelo estudo, instituições como a própria ONU através do ACNUR e a sociedade civil através da Cáritas. Portanto, o CONARE trata-se de um órgão tríplice, composto por governo, sociedade civil e as Nações Unidas (BARRETO, 2010).

Desde essa época, o Brasil tornou-se um forte empreendedor de dispositivos para ampliar e garantir a proteção dos refugiados, inclusive nos países do Mercado Comum do Sul (MERCOSUL), buscando vincular 
assuntos migratórios diretamente aos direitos humanos. O processo de expansão do engajamento brasileiro na proteção e integração dos refugiados manteve-se ao longo dos governos de Fernando Henrique Cardoso (FHC) (1995-2002), Luís Inácio Lula da Silva (2003-2010) e Dilma Rousseff (2011-2016).

Assim, percebe-se que a partir da redemocratização, o Brasil buscou uma maior inserção nos regimes internacionais, adequando-se ao Regime de Direitos Humanos construído no âmbito da ONU. Inclusive, o tema tornou-se um dos princípios norteadores da política externa brasileira, tendo lugar especial na agenda do governo FHC, que conferiu maior relevância à política para refugiados. Pode-se afirmar que ao longo desse período, a imersão brasileira em uma estrutura internacional marcada pela emergência de novos temas foi capaz de alterar as percepções do governo brasileiro sobre o papel que queria desempenhar no mundo. Seus interesses foram reorientados vis-à-vis as mudanças que ocorriam nas relações internacionais e que fizeram com o que o tema dos direitos humanos e direitos dos refugiados ganhassem maior dimensão internacional.

Assim, o governo brasileiro modificou sua atuação, agindo de acordo com as normas internacionais que se tornaram internalizadas e que passaram a conferir sentido às políticas que foram adotadas para acolhimento e proteção aos refugiados. Como afirma Finnemore (1996), os Estados inseridos em um contexto normativo incorporam valores, normas e papéis que passam a informar seu comportamento, agindo de acordo com o que consideram normativamente apropriado. Como resultado, observa-se a criação da Lei 9.474/97 que institucionalizou no ordenamento jurídico brasileiro normas internacionais como a Convenção de 1951, o Protocolo de 1967 e a Declaração de Cartagena de 1984, apontando para a adequação brasileira às regras e valores da comunidade internacional.

Assim, foi apenas com a redemocratização que a política brasileira para refugiados tomou um novo rumo, inserida em um processo mais amplo de mudança na política externa brasileira, que buscou se inserir no cenário internacional não mais via distância dos debates relacionados à temas sensíveis, mas através da busca da autonomia pela participação (FONSECA JÚNIOR, 1998).

As autoridades brasileiras, no governo FHC, ainda no contexto de implementação da legislação recém-aprovada, demonstraram preocupação em garantir que os refugiados recebidos pelo Brasil fossem integrados em suas novas comunidades, recepcionando uma missão do ACNUR para sediar os projetos-piloto de reassentamento ${ }^{8}$, coordenados pelo CONARE. Tais projetos de reassentamento coincidiram com a política externa proposta pelo presidente à época, que reivindicava que os direitos humanos fossem protegidos e consolidados, atuando ao lado das organizações internacionais com um discurso voltado aos ideais de cooperação e solidariedade (ANDRADE; MARCOLINI, 2002; MOREIRA, 2010). Conforme afirmam Andrade e Marcolini (2002, p.174), esse é o "resultado do intenso trabalho desenvolvido pelo ACNUR na região, durante os anos 90 , e da consolidação do processo democrático por que passa o país, desde a queda da ditadura, em meados dos anos $80^{\prime \prime}$.
8. 0 reassentamento é uma das soluções duradoras para o refugiado, juntamente com a repatriação voluntária e a reintegração local no primeiro país de asilo. É uma solução buscada pelo ACNUR para realocar indivíduos ou grupos de refugiados que correm perigo no país de primeiro asilo (DOMINGUEZ; BAENINGER, 2017, p.7). 
O planejamento do programa de reassentamento foi concluído em 2001, em um seminário que reuniu o ACNUR, algumas Organizações Não Governamentais (ONG’s) e autoridades do Governo Federal. Ao fim do processo, o Brasil deixou de ser um simples receptor daqueles que escapavam de perseguição em países da região para receber refugiados de outros continentes, sendo, ainda, uma opção para aqueles que necessitassem de reassentamento. Inclusive, o país foi o primeiro na região a regular o processo em sua normativa interna (ANDRADE; MARCOLINI, 2002; BARRETO, 2010). O acordo para reassentamento foi firmado entre o governo e o ACNUR e consta no artigo 46, da Lei 9.474/97 que dispõe que "o reassentamento de refugiados no Brasil se efetuará de forma planificada e com participação coordenada dos órgãos estatais e, quando possível, de organizações não governamentais, identificando áreas de cooperação e de determinação de responsabilidades" (DOMINGUEZ; BAENINGER, 2017, p.7).

Apesar do Brasil não reassentar um grande número de refugiados, a política foi importante para mostrar uma convergência com os valores defendidos pelo governo brasileiro no âmbito doméstico e no plano internacional, de respeito aos direitos humanos. Na época, cerca de 120 refugiados foram recebidos no país através do programa brasileiro de reassentamento e mesmo com os ataques terroristas em 2001, o governo brasileiro recepcionou 23 refugiados afegãos (SALLES; GONÇALVES, 2016).

Como se pode observar, o período FHC marcou a participação mais ativa do Brasil nos regimes internacionais, inclusive de direitos humanos, se refletindo em uma modificação na política externa e nas políticas públicas voltadas aos refugiados, como apontam a criação de uma legislação específica sobre o tema e o programa de reassentamento de refugiados.

Porém, é importante destacar, como afirmado por Finnemore (1996), March e Olsen (2011), que as lógicas podem coexistir. É possível que o Estado internalize regras e papéis de acordo com o que é considerado bom e adequado, mas que em um segundo momento, já adequado ao contexto normativo, empreenda cálculos custo-benefício, balizando sua ação por uma lógica das consequências. Assim, mesmo existindo um contexto normativo que orienta as ações do Estado, ele também se guia por seus interesses materiais.

Sendo assim, não foram apenas motivos ideacionais que influenciaram a adoção de uma nova postura do Brasil no mundo pós-Guerra Fria, visto que o país desejava resgatar suas credenciais e obter maior influência no âmbito regional e global, o que implicava modificar a imagem brasileira de um país violador dos direitos humanos para um país que os respeitava. Ademais, ao tentar projetar-se como líder na região através do patrocínio de pautas solidárias e humanitárias, o Brasil, ao mesmo tempo, buscou uma maior credibilidade na comunidade internacional, o que de certa forma fortalece a identidade brasileira de um país mediador e capaz de contribuir para soluções pacíficas, o que consequentemente apoia seu pleito por um assento permanente no Conselho de Segurança das Nações Unidas.

Portanto, apesar da lógica da adequação estar presente nesta nova etapa da política brasileira para refugiados, pode-se concluir que ambas as 
lógicas interagem, visto que de um lado existem os ideais humanitários, solidários e universais e de outro os interesses de médio e longo prazo da política nacional.

O governo seguinte, de Lula da Silva, apesar de promover diversos ajustes na condução da política externa tornando-a mais diversificada e autônoma, manteve muitas das diretrizes do governo anterior, como a ênfase no multilateralismo, a cooperação, a defesa dos direitos humanos, a adesão aos regimes internacionais e o respeito às organizações. No que tange ao tema do refúgio, Lula continuou investindo no tratamento da questão, no que diz respeito à formulação de políticas públicas e no âmbito internacional, voltando-se, sobretudo, ao âmbito regional (MOREIRA, 2010).

Durante o governo Lula, o Brasil fez parte da elaboração, em 2004, do Plano de Ação do México para Fortalecer a Proteção Internacional dos Refugiados na América Latina que visou a maior integração dos refugiados nas comunidades locais. Uma de suas maiores inovações, o Programa Regional de Reassentamento, formulado por iniciativa brasileira, reforçava a ideia de que o Brasil é um país que age baseando-se na cooperação e na solidariedade internacional, incentivando o compartilhamento de responsabilidades e destacando um papel de liderança brasileira. Nesse contexto, o Brasil aprofundou sua política de reassentamento, conferindo prioridade aos problemas colombianos, realizando missões no Equador e na Costa Rica para identificar possíveis refugiados para serem reassentados no país. Nessa época, o governo brasileiro buscava projeção como um defensor das causas humanitárias (DOMINGUEZ; BAENINGER, 2017; MOREIRA, 2010; AMORIM, 2010).

O governo Lula buscou, ainda, um estreitamento de laços com o ACNUR, reforçando o comprometimento brasileiro com os direitos dos refugiados. Também houve fortalecimento do papel da sociedade civil, mais especificamente das Cáritas e do Instituto de Migrações e Direitos Humanos, contribuindo para o avanço dos direitos dos refugiados em plano nacional e, ao mesmo tempo, para a construção da imagem brasileira de país receptor no plano externo (AMORIM, 2010; CÂNDIDO, 2013; ZIEMATH, 2011). No entanto, como destacam Salles e Gonçalves (2016), as iniciativas do período foram marcadas por dificuldades na integração local dos refugiados, indicando a ausência de uma estrutura eficiente de integração dos refugiados ao país.

O governo Dilma Rousseff, por sua vez, foi marcado por inúmeros acontecimentos no âmbito político e econômico doméstico que implicaram em dificuldades para o exercício de uma política ativa como a do período anterior. Todavia, a princípio se buscou manter os princípios que nortearam a política externa de seu antecessor.

Seu governo enfrentou no campo externo a crise de refugiados em âmbito global, o que gerou um aumento exponencial de pessoas deslocadas por motivos de perseguição em diversas regiões do mundo. Em 2011, o número era de 42,5 milhões, enquanto em 2016, eram 60 milhões de pessoas. Neste período, cresceram as solicitações de refúgio no país. Enquanto em 2011 o Brasil recebeu 3.220 solicitações de refúgio, em 2015 foram 28.670 solicitações (COMITÊ NACIONAL PARA REFUGIADOS, 
9. É importante lembrar que apesar do crescimento exponencial no número de solicitações de refúgio no Brasil, em padrões internacionais, esta quantidade ainda é baixa. Segundo dados do ACNUR (2016), no final de 2015,

3,2 milhões de migrantes aguardavam resposta a suas solicitações de refúgio somente nos países industrializados, o maior número já registrado pela organização. A Turquia é o país que mais abriga refugiados no mundo, um total de 2,5 milhões, enquanto o Líbano tem a maior concentração de refugiados em seu território: a cada mil habitantes, 183 são refugiados.
2016)9. A maior parte dos refugiados reconhecidos no país é de origem síria, nacionalidade que teve sua entrada facilitada com a simplificação da concessão de vistos humanitários, diante da grave crise enfrentada. O CONARE publicou, em 24 de setembro de 2013, no Diário Oficial da União a decisão de garantir visto especial às pessoas afetadas pelos conflitos armados na Síria e familiares que desejassem buscar refúgio no Brasil (ALTO COMISSARIADO DAS NAÇÕES UNIDAS, 2013).

Embora não haja previsões na Lei 9.474/97 para a concessão do refúgio por calamidade social e econômica grave ou catástrofes naturais e apesar da visão do CONARE de que é crucial a configuração de perseguição materializada ou fundado temor de perseguição, o Estado brasileiro não ignorou as correntes migratórias provenientes da crise humanitária no Haiti, país no qual lidera uma missão de estabilização da ONU desde 2004. O CONARE, conforme disposto na Resolução Normativa $n^{\circ} 13$, de 23 de março de 2007, encaminhou os pedidos de refúgio procedentes de nacionais haitianos entre 2010 e janeiro de 2012 ao Conselho Nacional de Imigração (CNIg), órgão vinculado ao Ministério do Trabalho, responsável por coordenar atividades referentes à imigração (RIBEIRO, 2015).

Segundo Ribeiro (2015, p. 1248):

Apenas em 2012 [...] é estabelecido um instrumento jurídico nacional especial-
mente destinado a nacionais do Haiti que almejassem à migração ao Brasil com
a previsão de concessão do visto permanente especial por razões humanitárias.
Até então, esta medida de proteção era excepcional, porém, a partir da adoção
da referida resolução, este passou a ser o procedimento padrão adotado no caso
da imigração de nacionais do Haiti com o objetivo de estimular a via de acesso
legal e combater a ação de redes de traficantes de pessoas.

A concessão do visto permite que o migrante obtenha documento de identidade e ingresse no Cadastro de Pessoa Física (CPF), garantindo acesso aos serviços públicos e à carteira de trabalho (RIBEIRO, 2015).

Contudo, a ampliação das solicitações de refúgio coincidiu com a grave crise econômica, o que fez com que o trabalho do ACNUR e demais parceiros fosse dificultado pela escassez de recursos em um contexto sensível (DIAS et al, 2011; ZIEMATH, 2011). Apesar das articulações com governos locais e a busca por melhores relações com instituições envolvidas na proteção aos refugiados, os desafios para a integração local se tornaram ainda mais evidentes no contexto economicamente desfavorável. Diversos estudos destacam as dificuldades que os refugiados encontram para obter acesso a serviços públicos e moradia, além dos problemas relacionados às condições de trabalho e discriminação. Também são salientados problemas como a baixa capacidade operacional do CONARE e a necessidade de reavaliar a burocratização e o próprio funcionamento do processo de concessão do refúgio (MOREIRA, 2014; JUBILUT; MADUREIRA 2014; SALLES; GONÇALVES, 2016). O governo brasileiro divulgou as ações que pretende implementar em conjunto com a sociedade civil, estados e municípios para aprimorar o sistema nacional de integração dos refugiados.

Apesar de ser claro o fortalecimento da lógica da adequação na política brasileira para refugiados após a redemocratização, o Brasil é o único país do MERCOSUL a não assinar nem ratificar a Convenção sobre a Proteção dos Direitos dos Trabalhadores Migrantes e Membros 
de Sua Família, que prevê maior proteção para o trabalhador estrangeiro (CONECTAS DIREITOS HUMANOS, 2015; NAÇÕES UNIDAS NO BRASIL, 2014). A demanda por mão-de-obra resultante do crescimento econômico do país, principalmente durante o período do governo Lula, tornou o Brasil um destino atraente para migrantes econômicos. Contudo, na grande maioria dos casos, aqueles que ingressaram no país ilegalmente, por temerem a deportação, não denunciam a exploração a que são submetidos, sem saber que a Resolução Normativa $n^{\circ} 93$ do Conselho Nacional de Imigração prevê a concessão de vistos de permanência para estrangeiros que estejam no país em situação de vulnerabilidade (ESTRANGEIROS..., 2013).

É importante salientar que durante o governo Rousseff começa a ser formulada a nova Lei de Migração, proposta no Projeto de Lei do Senado $\mathrm{n}^{\circ} 288$ de 2013 (PLS 228/2013), para substituir o Estatuto do Estrangeiro. A antiga lei, que ainda enxergava o migrante como uma ameaça em potencial, é considerada ultrapassada por representantes de partidos de diferentes ideologias políticas. A nova lei, considerada mais moderna, foi sancionada com vetos pelo presidente Michel Temer no dia 25 de maio de 2017 e facilita o acesso do imigrante à documentação necessária para sua permanência legal e acesso aos serviços públicos e trabalho formal, além de consolidar o visto humanitário. Ainda assim, apesar de representar um grande avanço à legislação nacional, a Lei de Migrações sofreu danos devido à sanção parcial, como por exemplo o veto à anistia aos imigrantes que entraram no Brasil até 6 de julho de 2016, independentemente da situação migratória anterior (MELITO, 2017; SENADO FEDERAL, 2017; PORTAL PLANALTO, 2017).

Percebe-se assim que embora o país esteja se adaptando às normas do Regime Internacional de Refugiados, internalizando princípios e regras, como evidenciam o Programa Regional de Reassentamento, os vistos especiais aos sírios e aos haitianos, a Lei 9.474/97, a nova Lei de Migrações e a busca por aprofundar a parceria público-privada para acolhimento e integração dos refugiados, ainda existem limitações no tratamento do tema, em que os interesses nacionais se sobrepõem à proteção dos indivíduos. Deste modo, nos governos Lula e Rousseff, apesar de alguns avanços, ainda se mantém a convivência da lógica das consequências com a lógica da adequação na política brasileira para refugiados.

Conclusão

Neste artigo, enfrentou-se o desafio de analisar como a lógica das consequências e a lógica da adequação orientaram a política brasileira para refugiados no período de 1950 até o governo Dilma Rousseff (20112016). Conclui-se que o comportamento do Estado brasileiro em relação aos direitos humanos e ao Direito Internacional dos Refugiados sofreu mudanças durante o período estudado. Ao longo dos anos, a lógica das consequências prevaleceu na política brasileira para refugiados, que se orientava por um viés pragmático como guia para as ações, deixando em segundo plano a dimensão normativa e humanitária, sugerida pelo regime internacional. 
Viu-se que nos anos 1950, a lógica das consequências foi preponderante na política brasileira, mesmo que o país tenha aderido às normas que emergiram no regime internacional de refugiados, como a Convenção de 1951. Sobressaiu neste momento o interesse de atrair migrantes para contribuírem no processo de desenvolvimento nacional, ao invés dos interesses humanitários, apesar do país ter se tornado o maior receptor de refugiados na América do Sul. Durante a ditadura militar prevaleceu com mais intensidade a mesma lógica, visando, principalmente, interesses de segurança, com enfoque em impedir a entrada de refugiados de regimes ditatoriais, por meio da continuidade da reserva geográfica e temporal e a não efetiva adesão do país às novas legislações sobre refugiados em âmbito internacional, como o Protocolo de 1967 e a Convenção de Cartagena de 1984.

Somente a partir da redemocratização, sobretudo nos anos 1990, que o Brasil aderiu a uma lógica da adequação, a partir de uma maior inserção nos regimes internacionais de direitos humanos. Posteriormente, a criação da Lei 9.474 de 1997 institucionalizou no ordenamento jurídico brasileiro as normas internacionais referentes aos direitos dos refugiados. Contudo, como exposto na seção anterior, podemos pensar que há uma convivência da lógica da adequação com a lógica das consequências no comportamento brasileiro, pois não foram somente motivos ideacionais que influenciaram a adoção de uma nova postura pelo Brasil, que também vislumbrou a possibilidade de melhorar sua imagem internacional, exercer papel de líder na região e ampliar sua credibilidade, fortalecendo o seu papel de mediador na temática da defesa dos direitos humanos e dos refugiados.

A maior dificuldade, do ponto de vista analítico, consiste em entender até que ponto a convivência das duas lógicas de comportamento interfere na formulação e implementação da política brasileira para refugiados, sobretudo em um cenário de crise econômica doméstica que convive com um grande contingente de pessoas solicitando acolhida e proteção. É possível que novamente a lógica das consequências prepondere no comportamento brasileiro? A lógica da adequação tende a preponderar, devido à internalização de normas que orientam o comportamento? A nova Lei de Migrações, sancionada com vetos pelo presidente Michel Temer, pode representar uma continuidade da postura em relação aos migrantes tomada pelos governos anteriores, onde predomina a convivência das duas lógicas? Essas questões não são objeto de investigação neste artigo, mas têm o potencial para fomentar futuros estudos que analisem a política para refugiados no momento atual.

Referências:

ALTO COMISSARIADO DAS NAÇÕES UNIDAS. Dados sobre Refúgio no Brasil: solicitações de refúgio por país de origem (2016). [S.1.]: ACNUR, 2016. Disponível em: $<$ http://www.acnur. org/portugues/recursos/estatisticas/dados-sobre-refugio-no-brasil/>. Acesso: 20 mar. 2017.

ALTO COMISSARIADO DAS NAÇÕES UNIDAS. Sírios terão visto humanitário para entrar no Brasil. Brasília: ACNUR, 24 set. 2013. Disponível em: < http://www.acnur.org/portugues/ noticias/noticia/sirios-terao-visto-humanitario-para-entrar-no-brasil/>. Acesso em: 09 jun. 2017.

ALTO COMISSARIADO DAS NAÇÕES UNIDAS. Global trends forced displacement in 2015. [S.1.]: UNHCR, 2016. Disponível em: < http://www.unhcr.org/576408cd7>. Acesso em: 20 mar. 2017. 
AMORIM, Celso. A política externa brasileira no governo do Presidente Lula (2003-2010): uma visão geral. Revista Brasileira de Política Internacional, v. 53, n. spe, p.214-240, 2010.

ANDRADE, José H. Fischel; MARCOLINI, Adriana. A política brasileira de proteção e de reassentamento de refugiados: breves comentários sobre suas principais características. Revista Brasileira de Política Internacional, v. 45, n. 1, p. 168-176, 2002.

BARNETT, Michael; FINNEMORE, Martha. Rules for the world: international organizations in global politics. Nova York: Cornell University Press, 2004, p. 73-120.

BARRETO, Luiz Paulo Teles Ferreira. A lei brasileira de refúgio: sua história. In: BARRETO, Luiz Paulo Teles Ferreira (Org.). Refúgio no Brasil: a proteção brasileira aos refugiados e seu impacto nas Américas. Brasília: Ministério da Justiça, 2010. p. 12-21.

BRASIL. Constituição da República Federativa do Brasil de 1988. Nós, representantes do povo brasileiro, reunidos em Assembleia Nacional Constituinte para instituir um Estado Democrático, destinado a assegurar o exercício dos direitos sociais e individuais[...]. Diário Oficial da União, Brasília, 5 out. 1988. Disponível em: <http://www.planalto.gov.br/ccivil_03/constituicao /constituicao.htm>. Acesso em: 07 nov. 2017.

BRASIL. Decreto n ${ }^{\circ}$ 98.602, de 19 de dezembro de 1989. Dá nova redação ao Decreto no 50.215 , de 28 de janeiro de 1961 que promulgou a Convenção relativa ao Estatuto dos Refugiados, concluída em Genebra, em 28 de julho de 1951. Diário Oficial da União, Brasília, 20 dez. 1989. Disponível em:< http://www.planalto.gov.br/ccivil_03/decreto/1980-1989/D98602.htm>. Acesso em: 07 nov. 2017.

BRASIL. Lei n ${ }^{\circ}$ 6.815, de 19 de agosto de 1980. Define a situação jurídica do estrangeiro no Brasil, cria o Conselho Nacional de Imigração. Diário Oficial da União, Brasília, 21 ago. 1980. Disponível em:< http://www.planalto.gov.br/ccivil_03/leis/L6815.htm>. Acesso em: 07 nov. 2017.

BRASIL. Lei $\mathrm{n}^{\circ}$ 9.474, de 22 de julho de 1997. Define mecanismos para a implementação do Estatuto dos Refugiados de 1951, e determina outras providências. Diário Oficial da União, Brasília, 23 jul. 1997. Disponível em:< http://www.planalto.gov.br/ccivil_03/leis/L9474.htm>. Acesso em: 07 nov. 2017.

CÂNDIDO, Mônica Tse. Política externa, Direitos Humanos e Refugiados: de FHC a Dilma. In: ENCONTRO NACIONAL DA ASSOCIAÇÃO BRASILEIRA DE RELAÇÕES INTERNACIONAIS, 4., 2013, Belo Horizonte. Anais... Belo Horizonte: ABRI, 2013. Disponível em: <http:// www.encontronacional2013.abri.org.br/conteudo/view?ID_CONTEUDO=876> . Acesso em: 20 mar. 2017.

COMITÊ NACIONAL PARA REFUGIADOS. Ministério da Justiça. Sistema de refúgio brasileiro: desafios e perspectivas. [S.1.]: CONARE, 2016. Disponível em: $<$ http://www.acnur.org/ t3/fileadmin/Documentos/portugues/Estatisticas/Sistema_de_Refugio_brasileiro_-_Refugio_em_numeros_-_05_05_2016.pdf $>$. Acesso em: 20/03/2017.

CONECTAS DIREITOS HUMANOS. $1^{\circ}$ de maio: dia de todos os trabalhadores: campanha pede adesão do Brasil a tratado internacional que protege trabalhadores migrantes. São Paulo: Conectas Direitos Humanos, 30 abr. 2015. Disponível em: $<$ http://www.conectas.org/pt/ acoes/politica-externa/noticia/34890-1o-de-maio-dia-de-todos-os-trabalhadores $>$. Acesso em: 08/06/2017.

CONVENÇÃO DAS NAÇÕES UNIDAS RELATIVA AO ESTATUTO DOS REFUGIADOS. Convenção de 1951 relativa ao estatuto dos refugiados. Genebra: ACNUR, 28 jul. 1951. Disponível:< http://www.pucsp.br/IIIseminariocatedrasvm/documentos/convencao_de_1951_relativa_ao_estatuto_dos_refugiados.pdf $>$. Acesso em: 06 nov. 2017.

DIAS, Carolina Sanches Lecornec et al. Política brasileira para refugiados: política de Estado ou política de governo?. Fronteira, v. 10, n. 19, p. 25-39, 2011.

DOMINGUEZ, Juliana Arantes; BAENINGER, Rosana. Programa de reassentamento de refugiados no Brasil. [S.1.]: Conjur, 2017. Disponível em: <http://s.conjur.com.br/dl/programa-reassentamento-refugiados.pdf $>$. Acesso em: 20 mar. 2017.

ESTRANGEIROS resgatados de escravidão no Brasil são 'ponta de iceberg'. [S.1.]: BBC Brasil, 13 maio 2013. Disponível em: <http://www.bbc.com/portuguese/noticias/2013/05/130508_trabescravo_estrangeiros_fl>. Acesso em: 08 jun. 2017.

FERREIRA, Aloysio Nunes. Projeto de Lei do Senado $\mathbf{n}^{\circ} \mathbf{2 8 8}$, de 2013. Institui a Lei de Migração e regula entrada e estada de estrangeiros no Brasil. Disponível em: $<$ http://www25.senado. leg.br/web/atividade/materias/-/materia/113700>. Acesso em: 07 nov. 2017.

FINNEMORE, Martha. National interests in international society. Ithaca: Cornell University Press, 1996. 
FINNEMORE, Martha. SIKKINK, Kathryn. International norm dynamics and political change. International Organization, v. 52, n. 4, 1998.

FONSECA JÚNIOR, Gelson. A legitimidade e outras questões internacionais: poder e ética entre as nações. São Paulo: Paz e Terra, 1998.

JUBILUT, Liliana Lyra. O direito internacional dos refugiados e sua aplicação no ordenamento jurídico Brasileiro. São Paulo: Método, 2007.

JUBILUT, Liliana Lyra; APOLINÁRIO, Silvia. A população refugiada no Brasil: em busca da proteção integral. Universitas - Relações Internacionais, Brasília, v.6, n.2, p. 9-38, jul.//-dez. 2008.

JUBILUT, Liliana Lyra; MADUREIRA, André de Lima. Os desafios de proteção aos refugiados e migrantes forçados no marco de Cartagena +30. REMHU, Revista Interdisciplinar da Mobilidade Humana, Brasília, v. 22, n.43, jul/dez. 2014.

KRASNER, Stephen. Structural causes and regime consequences: regimes as intervening variables. International Organization, v.36, n.2, 1982.

MARCH, James G.; OLSEN, Johan P. The logic of appropriateness. The Oxford handbook of political science, jul. 2011.

MELITO, Leandro. Especialistas avaliam que Lei de Migração representa avanço, apesar de vetos. Brasília: Agência Brasil, 25 maio 2017. Disponível em: <http://agenciabrasil.ebc.com.br/ politica/noticia/2017-05/especialistas-avaliam-que-lei-de-migracao-representa-avanco-apesar-de-vetos>. Acesso em: 08 jun. 2017.

MESSARI, Nizar; NOGUEIRA, João Pontes. Teoria das Relações Internacionais: correntes e debates. Rio de Janeiro: Elsevier, 2005.

MOREIRA, Julia Bertino. Redemocratização e direitos humanos: a política para refugiados no Brasil. Revista Brasileira de Política Internacional, v. 53, n. 1, p. 111-129, 2010.

MOREIRA, Julia Bertino. Refugiados no Brasil: reflexões acerca do processo de integração local. Revista Interdisciplinar da Mobilidade Humana, v. 22, n. 43, 2014.

MOREIRA, Julia Bertino. Política em relação aos refugiados no Brasil. 2012. 351 f. Tese (Doutorado) - Instituto de Filosofia e Ciências Humanas, Universidade Estadual de Campinas. Campinas, 2012.

NAÇÕES UNIDAS NO BRASIL. Direitos dos migrantes: comitê da ONU pede que países ratifiquem tratado global. [S.1.]: ONURBR, 7 abr. 2014. Disponível em: $<$ https://nacoesunidas. org/direitos-dos-migrantes-comite-da-onu-pede-que-paises-ratifiquem-tratado-global/>. Acesso em: 08 jun. 2017.

ONUF, Nicholas. Constructivism: a user's manual. In: KUBÁLKOVÁ, Vendulka; ONUF, Nicholas; KOWERT, Paul (Ed.). International relations in a constructed world. Armonk: M. E. Sharpe, 1998. Chap. 3, p. 58- 78.

ORGANIZAÇÃO DAS NAÇÕES UNIDAS. Declaração Universal dos Direitos Humanos. [S.1.]: ONU, 1948. Disponível em: <http://www.ohchr.org/EN/UDHR/Documents/UDHR_ Translations/por.pdf>. Acesso em: 11mar. 2017.

PIOVESAN, Flávia. O direito de asilo e a proteção internacional dos refugiados. In: ARAÚJO, Nadia de; ALMEIDA, Guilherme Assis. (Coord.). O direito internacional dos refugiados: uma perspectiva brasileira. Rio de Janeiro: Renovar, 2001, p. 27-64.

PORTAL PLANALTO. Presidente sanciona a Lei de Migração com vetos. Brasília: Planalto, 25 maio 2017. Disponível em: <http://www2.planalto.gov.br/acompanhe-planalto/noticias/2017/05/presidente-sanciona-a-lei-de-migracao-com-vetos $>$. Acesso em: 05 jun. 2017.

RIBEIRO, Victor Matheus Portela. Condição jurídica do imigrante no Brasil: uma reflexão sobre as causas motivadoras da migração e a regulação do visto humanitário como medida de complementar. In: CONGRESSO DO MESTRADO EM DIREITO E SOCIEDADE DO UNILASALLE, 2015, Canoas. Sociology of law on the move 2015: perspectives from Latin America. Canoas: Unilasalle, 2015. Disponível em: <http://www.sociologyoflaw.com.br/IMG_SYSTEM/17-GT-imigracao-trafico-de-pessoas-e-refugio.pdf $>$. Acesso em: 09 jun. 2017.

RITTBERGER, Volker; MAYER; Peter; HASENCLEVER, Andreas. Integrating theories of international. Review of International Studies, v. 26, n.1, 2000.

SALLES, Denise; GONÇALVES, Fernanda Cristina Nanci Izidro. A atuação do Estado brasileiro na proteção dos refugiados: a distância entre a legislação e a garantia dos direitos humanos. In: SEMINÁRIO DE RELAÇÕES INTERNACIONAIS GRADUAÇÃO E PÓS-GRADUAÇÃO DA ABRI, 3., Florianópolis. Anais... Florianópolis: UFSC, 2016. Disponível em: < http://www.se- 
minario2016.abri.org.br/resources/anais/23/1474581913_ARQUIVO_Artigo_ABRIfinal.pdf>. Acesso em: 20 mar.2017.

SALLES, Maria do Rosário Rolfsen. A política imigratória brasileira no pós-segunda guerra mundial e os refugiados: uma leitura da Revista de imigração e colonização. Cena Internacional, v. 9, n. 2, 2007.

SENADO FEDERAL. Nova Lei de Migração é sancionada com vetos. Brasília: Senado Notícias, 25 maio 2017. Disponível em: <http://www12.senado.leg.br/noticias/materias/2017/05/25/nova-lei-de-migracao-e-sancionada-com-vetos $>$. Acesso em: 05 jun.2017.

TRINDADE, Antônio Augusto Cançado. Dilemas e desafios da proteção internacional dos direitos humanos no limiar do século XXI. Revista Brasileira de Política Internacional, v. 40, n. 1, p. 167-177, 1997.

WENDT, Alexander. Driving with the rearview mirror: on the rational science of institutional design. International Organization, v. 55, n. 4, p. 1019-1049, 2001.

ZIEMATH, Gustavo Gerlach da Silva. Um balanço inicial da política externa do Governo Dilma: continuidades. Mundorama, 2011. Disponível em: < http://mundorama.net/2011/05/09/ um-balanco-inicial-da-politica-externa-do-governo-dilma-continuidades-por-gustavo-gerlach-da-silva-ziemath/>. Acesso em: 20 ago. 2016. 